\title{
Cobalt-Catalyzed Reductive Coupling of Activated Alkenes with Alkynes
}<smiles>CC#Cc1ccccn1</smiles><smiles>C=CC(C)=O</smiles>
(1.2 equiv)

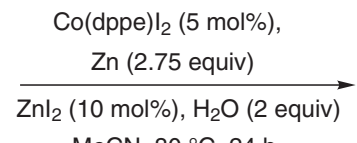<smiles>CC(=O)CC/C(C)=C/c1ccccn1</smiles>
$84 \%$ yield<smiles>C#CCCCC=CC(C)=O</smiles>

Co(dppe) $\mathrm{l}_{2}(5 \mathrm{~mol} \%)$,

$\frac{\mathrm{Zn}(2.75 \text { equiv) }}{\mathrm{Znl}_{2}(10 \mathrm{~mol} \%), \mathrm{H}_{2} \mathrm{O} \text { (2 equiv) }}$

$\mathrm{MeCN}, 80^{\circ} \mathrm{C}, 8 \mathrm{~h}$

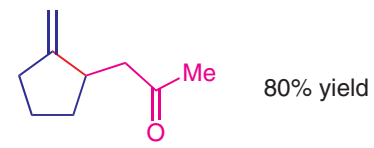<smiles>C=CC(=O)OC</smiles>

Co(dppe) $I_{2}(5$ mol\%)

$$
\underset{\mathrm{ZnI}_{2}(10 \mathrm{~mol} \%), \mathrm{H}_{2} \mathrm{O} \text { (2 equiv) }}{\mathrm{Zn}(2.75 \text { equiv) }}
$$

(1.2 equiv) MeCN-dioxane $(1: 6), 80^{\circ} \mathrm{C}, 12 \mathrm{~h}$<smiles>CC(C)C1OC(=O)CC/C1=C/c1ccccc1</smiles>

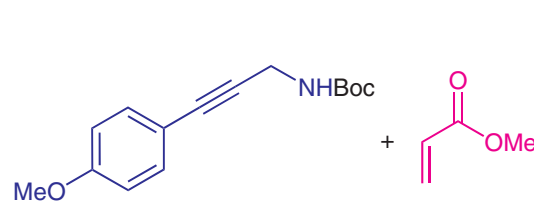

(1.2 equiv)

$$
\text { Co(dppe) } I_{2}(5 \mathrm{~mol} \%) \text {, }
$$

\section{1) $\quad \mathrm{Zn}(2.75$ equiv)}

$\mathrm{Znl}_{2}$ (10 mol\%), $\mathrm{H}_{2} \mathrm{O}$ (2 equiv) MeCN-dioxane (1:6), $80^{\circ} \mathrm{C}, 12 \mathrm{~h}$

2) TFA-THF, reflux, $1 \mathrm{~h}$

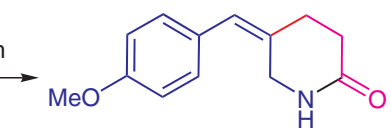

$72 \%$ yield
Significance: Catalytic processes that effect a new $\mathrm{C}-\mathrm{C}$ bond formation are of continuous interest for organic synthesis. In this work, a novel coupling reaction of a broad range of alkynes with electron-deficient alkenes such as acrylates, acrylonitriles, and enals is reported. The reaction can be performed intramolecularly, affording functionalized cyclic compounds like lactones or lactams. This is a general and practical method for the construction of relatively complex carbon scaffolds from rather simple precursors.
Comment: The reaction presumably proceeds via a Co(I)-Co(III) catalytic cycle, where the key step is the transformation of the alkene-alkyne-Co(I) complex into a five-membered cobalacycle [containing $\mathrm{Co}(\mathrm{III})$ ]. The method is limited to disubstituted alkenes, but still is quite general in scope. Internal alkynes without aromatic substituents give mixtures of regioisomers. The products can undergo useful further transformations (see the last example in the scheme), increasing the reaction utility. 